\title{
Bacterivory in the common foraminifer Ammonia tepida: Isotope tracer experiment and the controlling factors
}

\author{
Pierre-Yves Pascal ${ }^{a,}{ }^{*}$, Christine Dupuy $^{a}$, Pierre Richard $^{a}$ and Nathalie Niquil ${ }^{a}$
}

\begin{abstract}
a Littoral, Environnement et Sociétés (LIENSS) UMR 6250 CNRS-Université de La Rochelle, 2 Rue Olympe de Gouges, 17042 La Rochelle cedex, France
\end{abstract}

*: Corresponding author : Pascal P.Y., email address : pypascal@univ-Ir.fr

\begin{abstract}
:
The majority of sediment dweller foraminifera are deposit feeders. They use their pseudopodia to gather sediment with associated algae, organic detritus and bacteria. Uptake of bacteria by foraminifera have been observed but rarely quantified. We measured uptake of bacteria by the common foraminifera Ammonia tepida using ${ }^{15} \mathrm{~N}$ pre-enriched bacteria as tracers. In intertidal flats, seasonal, tidal and circadian cycles induce strong variations in environmental parameters. Grazing experiments were performed in order to measure effects of abiotic (temperature, salinity and irradiance) and biotic (bacterial and algal abundances) factors on uptake rates of bacteria. In mean conditions, A. tepida grazed $78 \mathrm{pgC}$ ind ${ }^{-1} \mathrm{~h}^{-1}$ during the first eight hours of incubation, after which this uptake rate decreased. Uptake of bacteria was optimal at $30^{\circ} \mathrm{C}$, decreased with salinity and was unaffected by light. Above $7 \times 10^{8}$ bacteria ml wt sed ${ }^{-1}$, uptake of bacteria remained unchanged when bacterial abundance increased. Algal abundance strongly affected algal uptake but did not affect uptake of bacteria. As uptake of bacteria represented 8 to $19 \%$ of microbes (algae plus bacteria) uptake, Ammonia seemed to be mainly dependant on algal resource.
\end{abstract}

Keywords: Bacteria; Environmental factor; Foraminifera; Grazing; Mudflat; Prey abundance; Trophoecology 


\section{Introduction}

Benthic foraminifera are heterotrophic protozoa that have the morphological characteristics of pseudopodia and a test with one or more chambers. Since the Cambrian era, they have been present in a wide range of environments, from shallow brackish waters to deepest oceans. They are used as proxies for paleoecological studies because they are wide spread, numerous and well preserved. In recent times, foraminifera increasingly appeared as dominant members of benthic communities in both shallow and deep-sea environments (Snider et al. 1984; Alongi 1992; Gooday et al. 1992; Moodley et al. 1998; Moodley et al. 2000), suggesting that they may play an important role in food webs (Altenbach 1992; Linke et al. 1995).

Foraminifera exhibit a wide range of trophic behaviours: dissolved organic matter (DOM) uptake, herbivory, carnivory, suspension feeding and most commonly, deposit feeding (Lipps 1983). Deposit feeders are omnivorous, using their pseudopodia to gather fine-grained sediment with associated bacteria, organic detritus and, if available, algal cells. As a large part of organic detritus is indigestible, it must be cycled by bacteria before becoming available to deposit feeders (Levinton 1979). Benthic bacteria are highly abundant and productive in benthic sediments. Due to their high nutritional value they are suspected to be an important resource for sediment dwelling fauna.

Bacteria could play a major role or be an obligatory item in foraminiferal nutrition. Several littoral benthic foraminifera require bacteria to reproduce (Muller and Lee 1969) and have been shown to selectively ingest bacteria according to strain (Lee et al. 1966; Lee and Muller 1973). Some epiphytic foraminifera show a farming strategy. They produce nutrient-rich substrate for bacteria and then ingest cultured bacteria (Langer and Gehring 1993). Foraminifera are also able to feed actively on bacterial biofilms (Bernhard and Bowser 1992). Bacteria may also play a symbiotic role in bathial species of foraminifera (Bernhard 2003). Uptake of bacteria by $\underline{\text { Ammonia }}$ has been displayed using direct food vacuole observation 
50 (Goldstein and Corliss 1994) and bacteria labelled with fluorescent dyes (Langezaal et al.

51 2005). Nevertheless, those studies do not give access to quantitative data concerning the uptake rate of bacteria, and the precise role that bacteria play in foraminiferal nutrition remains elusive. Assessing grazing rate on bacteria remains a major point that must be documented to determine the role that foraminifera play in benthic food webs.

Ammonia is one of the most common genera of benthic foraminifera with a worldwide distribution in inner shelf, estuarine, and salt marsh environments (Murray 1991). One remarkable characteristic of this genus is its ability to survive over a broad range of temperatures, salinities, and seasonal regimes (Bradshaw 1961; Walton and Sloan 1990).

The aim of this study is to assess experimentally in different controlled conditions uptake rates of bacteria by Ammonia from an intertidal mudflat habitat (Marennes-Oléron, France).

$61{ }^{15} \mathrm{~N}$ enriched bacteria were used as tracers to determine uptake rate of bacteria (Pascal et al. 2008). This habitat is subject to large and quick changes in many environmental features. Three relevant time scales drive these environmental variations: long-term (seasonal cycle), medium-term (lunar cycle) and short-term (solar and tidal cycles) (Guarini et al. 1997). Since these variations may influence foraminiferal feeding behaviour, grazing experiments were 66 performed in order to evaluate effects of abiotic (temperature, salinity and irradiance) and biotic (bacterial and algal abundances) factors on uptake rates of bacteria. 


\section{Experimental procedure}

\section{Study site}

The Brouage intertidal mudflat is located in the eastern part of the Marennes-Oléron Bay (Atlantic coast of France). Meteorological conditions exhibit a strong seasonality typical of a temperate climate. Temperature and salinity of emerged sediments are more extreme during summer tidal cycles (Guarini et al. 1997). Minimum and maximum mud temperatures are $5^{\circ} \mathrm{C}$ and $34^{\circ} \mathrm{C}$ respectively. The maximum daily range of mud temperature due to emersion and immersion cycle reaches $18^{\circ} \mathrm{C}$ (Guarini et al. 1997). Salinity of overlaying water is controlled by the river Charente freshwater input, ranging from 25 to $35 \%$ over the year (Héral et al. 1982). Salinity of the upper layers of sediment may also decrease with rainfall. The sediment surface irradiance shifts from dark during submersion and night emersions to high levels of incident light during daytime emersions. This irradiance can reach $2000 \mu \mathrm{M}$ of photons $\mathrm{m}^{-2} \mathrm{~s}^{-1}$ (Underwood and Kromkamp 2000). Details of numerous benthic organisms and processes are available concerning this intertidal zone (gathered in Leguerrier et al. 2003; Leguerrier et al. 2004; Degré et al. 2006).

\section{Preparation of ${ }^{15} \mathrm{~N}$ enriched bacteria}

Superficial sediment $(1 \mathrm{~cm}$ depth) was collected on the Brouage mudflat $(45,55,074 \mathrm{~N}$; $1,06,086 \mathrm{~W})$. One $\mathrm{ml}$ of the collected sediment was added to $20 \mathrm{ml}$ of bacterial liquid culture medium and kept in darkness during 24 hours at $13^{\circ} \mathrm{C}$. The composition of this culture medium were previously described in Pascal et al. (2008). This primary culture was then subcultured during 24 hours under the same conditions to get approximately $2 \times 10^{9}{\text { cells } \mathrm{ml}^{-}}^{-}$

${ }^{1}$. Finally, bacteria were collected in $0.2 \mu \mathrm{m}$ filtered seawater after 3 centrifugations $(3500 \mathrm{~g}$, $10 \mathrm{mn}, 20^{\circ} \mathrm{C}$ ), frozen in liquid nitrogen and kept frozen at $-80^{\circ} \mathrm{C}$ until grazing experiments. 
An axenic clone of the diatom Navicula phyllepta (CCY 9804, Netherlands Institute of Ecology NIOO-KNAW, Yerseke, The Netherlands), the most abundant diatom species in the study area (Haubois et al. 2005), was cultured in medium described by Antia and Cheng (1970) and containing $\mathrm{NaH}^{13} \mathrm{CO}_{3}(4 \mathrm{mM})$. Diatoms were concentrated by centrifugation $\left(1500 \mathrm{~g}, 10 \mathrm{mn}, 20{ }^{\circ} \mathrm{C}\right)$, washed three times to remove the ${ }^{13} \mathrm{C}$-bicarbonate, and freeze-dried.

\section{Quantification of bacteria and algae abundance}

In order to determine the ratio between enriched and non-enriched preys in microcosms, abundances of bacteria and algae were assessed. To separate bacteria from sediment particles, incubation in pyrophosphate $(0.01 \mathrm{M}$ during at least $30 \mathrm{~min})$ and sonication $(60 \mathrm{~W})$ were performed. Bacteria from both sediment and culture were labelled using 4.6-diamidino-2phenylindole dihydrochloride (DAPI) $\left(2500 \mu \mathrm{g} \mathrm{l^{-1 }}\right.$ ), filtered onto $0.2 \mu \mathrm{m}$ Nucleopore black filter (Porter and Feig 1980) and then counted by microscopy. We check the absence of ciliate and flagellate in bacterial culture during this microscope observation step. Abundance of diatom in sediment was assessed using $\mathrm{Chl} a$ as a proxy, measured using fluorometry (Lorenzen 1966).

\section{Grazing experiments}

Incubation of enriched bacteria and algae with foraminifera were performed in Petri dishes (4.5 cm diameter). Experiments were done in standardized condition similar to field ones: temperature $\left(20^{\circ} \mathrm{C}\right)$, irradiance (darkness), salinity $\left(31 \%\right.$ ) , bacterial abundance $\left(10.5 \times 10^{8}\right.$ cells $\left.\mathrm{ml} \mathrm{wt} \mathrm{sed}{ }^{-1}\right)$ and algal abundance $\left(15 \mu \mathrm{gChla} \mathrm{g} \mathrm{dry} \mathrm{sed}^{-1}\right)$. For each type of experiment, one environmental incubation factor was modified in order to determine its impact on foraminifera grazing activity. Each experiment was carried out in triplicate, along with triplicate controls. Control samples were frozen $\left(-80^{\circ} \mathrm{C}\right)$ in order to kill foraminifera. 
During the ebb tide of $13^{\text {th }}$ of March 2006, one sample of the first centimetre of sediment was collected from the Brouage intertidal mudflat (France). First, the sediment was sieved on a $500 \mu \mathrm{m}$ mesh in order to remove macrofauna. Then, it was sieved on a $200 \mu \mathrm{m}$ mesh to extract large foraminifera. One $\mathrm{ml}$ of the sediment remaining on the mesh was put in each microcosm. Sediment that passed through the $200 \mu \mathrm{m}$ mesh was sieved through a $50 \mu \mathrm{m}$ mesh. Fraction passing through the mesh was mixed with ${ }^{15} \mathrm{~N}$ enriched bacteria. This slurry contained $10.5 \times 10^{8}$ cells $\mathrm{ml}$ of wet sediment ${ }^{-1}$ with a ratio of total and enriched bacteria of 1.5. Four $\mathrm{ml}$ of this slurry were put in each microcosm.

First, for the calculation of grazing rates, a kinetic study was realised to validate the linear or hyperbolic uptake kinetics. Incubations for this kinetic study were run during variable times ( 1 to 12 hours). As all other experiments were run for 5 hours, this first step is necessary to check the linear uptake during the first five hours of incubation.

For each type of experiment one environmental incubation factor was modified. Light effect was tested with one irradiance $\left(83 \mu \mathrm{M}\right.$ of photons $\left.\mathrm{m}^{-2} \mathrm{~s}^{-1}\right)$. In order to decrease salinity, cultured bacteria were rinsed with $0.2 \mu \mathrm{m}$ filtered sea-water diluted with $0.2 \mu \mathrm{m}$ filtered fresh water (final salinity of $18 \%$ ). Bacterial abundance was modified adding various quantities of bacteria enriched in ${ }^{15} \mathrm{~N}$. Bacterial abundances (total enriched and non-enriched) tested were 4, 7 and 17 cells $\mathrm{ml}$ wt $\operatorname{sed}^{-1}$ with respectively the following ratio between abundance of total and enriched bacteria: 6.1, 2.0 and 1.3. Algal abundance was modified adding various

134 quantities of cultured $\underline{N}$. phyllepta enriched in ${ }^{13} \mathrm{C}$ while bacterial abundances (total enriched 135 and non-enriched) were kept constant at $10 \times 10^{8}$ cell ml $^{-1}$. Algal abundance (total enriched 136 and non-enriched) were 26,64 and $114 \mu \mathrm{gChla} g$ dry sed ${ }^{-1}$ with respectively the following 137 ratio between abundance of total and enriched algae: $2.4,1.3$ and 1.2.

138 Incubations were stopped by freezing the microcosms at $-80^{\circ} \mathrm{C}$. Samples were thawed and 139 stained with rose Bengal in order to identify freshly dead foraminifera. For each sample, 150 
140 specimens of the species $\underline{\text { A. tepida }}$ were picked up individually and cleaned of any adhering

141 particles. Samples from experiments with ${ }^{13} \mathrm{C}$ enriched $\underline{N}$. phyllepta were processed with $\mathrm{HCl}$

$1420.1 \mathrm{M}$ in silver boats to remove any inorganic carbon.

$143 \quad$ Isotope analysis and calculations

$144 \quad \delta^{15} \mathrm{~N}$ and $\delta^{13} \mathrm{C}$ of prey (bacteria and algae) and grazers (A. tepida) were measured using an

145 EA-IRMS (Isoprime, Micromass, UK). Nitrogen isotope composition is expressed in the delta 146 notation $\left(\delta^{15} \mathrm{~N}\right)$ relative to air $\left.\mathrm{N}_{2}: \delta^{15} \mathrm{~N}=\left[\left({ }^{15} \mathrm{~N} /{ }^{14} \mathrm{~N}\right)_{\text {sample }} /\left({ }^{15} \mathrm{~N} /{ }^{14} \mathrm{~N}\right)_{\text {reference }}\right)-1\right] \times 1000$. Carbon

147 isotope composition is expressed in the delta notation $\left(\delta^{13} \mathrm{C}\right)$ relative to Vienna Pee Dee 148 Belemnite $($ VPDB $\left.): \delta^{13} \mathrm{C}=\left[\left({ }^{13} \mathrm{C} /{ }^{12} \mathrm{C}\right)_{\text {sample }} /\left({ }^{13} \mathrm{C} /{ }^{12} \mathrm{C}\right)_{\text {reference }}\right)-1\right] \times 1000$.

149 Incorporation of ${ }^{15} \mathrm{~N}$ is defined as excess above background ${ }^{15} \mathrm{~N}$ (control experiment) and 150 is expressed in terms of specific uptake $(I) . I$ was calculated as the product of excess ${ }^{15} \mathrm{~N}(E)$ 151 and biomass of $\mathrm{N}$ per grazer. $I$ was converted in bacterial carbon grazed using $\mathrm{C} / \mathrm{N}$ ratio of 152 bacteria. $E$ is the difference between the background $\left(F_{\text {background }}\right)$ and the sample $\left(F_{\text {sample }}\right){ }^{15} \mathrm{~N}$

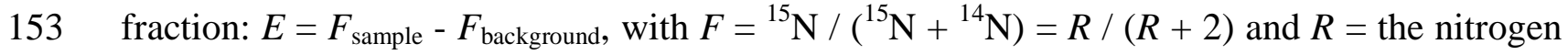

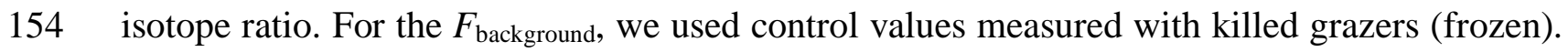
$155 R$ was derived from the measured $\delta^{15} \mathrm{~N}$ values as: $R=\left(\left(\delta^{15} \mathrm{~N} / 1000\right)+1\right) \times R$ airN $\mathrm{N}_{2}$ where $R_{\text {airN }}$ $156=7.35293 \times 10^{-3}($ Mariotti 1982). The uptake of bacteria was calculated as Uptake $=(I \times(\%$

$\left.157 \mathrm{C}_{\text {enriched bacteria }} / \% \mathrm{~N}_{\text {enriched bacteria }}\right) /\left(F_{\text {enriched bacteria }} \times\right.$ incubation time $)$. This uptake was 158 multiplied by the ratio between the abundance of total and enriched bacteria determined by 159 DAPI counts.

160 Incorporation of ${ }^{13} \mathrm{C}$ was calculated analogously, with $F={ }^{13} \mathrm{C} /\left({ }^{13} \mathrm{C}+{ }^{12} \mathrm{C}\right)=R /(R+1)$, $161 R$ airN 2 is replaced by $R_{\mathrm{VPDB}}=0.0112372$ and Uptake $=I /\left(F_{\text {enriched bacteria }} \times\right.$ incubation time $)$.

162 The uptake measured was multiplied by the ratio between the abundance of total and enriched 163 diatom, determined from fluorometrical measurements. 
Enriched $\underline{N}$. phyllepta carbon consisted of $22.95 \pm 0.54 \%{ }^{13} \mathrm{C}$. The $\mathrm{C} / \mathrm{N}$ ratio of enriched

165 bacteria was 3.49 and bacterial nitrogen consisted of $2.88 \pm 0.03 \%{ }^{15} \mathrm{~N}$. The average weight of

$166 \underline{\text { A. tepida }}$ used was $18.1 \pm 3 \mu \mathrm{g}$ DW ( $\mathrm{n}=115$ samples of 150 specimens each). Decalcified

167 specimens of $\underline{\text { A. tepida }}$ were composed on average of $1.03 \pm 0.23 \mu \mathrm{g}$ of $\mathrm{C}$ and $0.15 \pm 0.03 \mu \mathrm{g}$

168 of $\mathrm{N}$. Uptake expressed as $\mathrm{gC}_{\text {bacteria }} \mathrm{h}^{-1} \mathrm{gC}_{\underline{\text { Ammonia }}}{ }^{-1}$ was obtained by dividing uptake of bacteria

$169\left(\mathrm{gC} \mathrm{ind}^{-1} \mathrm{~h}^{-1}\right)$ by $\underline{\text { A. tepida }}$ decalcified mean weight $\left(\mathrm{gC}\right.$ ind $\left.^{-1}\right)$.

170 Variations of uptake rates according to salinity and irradiance were tested using bilateral

171 independent-samples t-tests. One-way analyses of variance (ANOVA) were used in order to

172 test the impact of temperature and algal and bacterial abundance on uptake rates of bacteria

173 and algae. The Tukey test was used for post-hoc comparisons.

\section{Results}

175 Foraminiferal isotopic compositions and rates of bacterial and algal uptakes rates are 176 presented in Table 1.

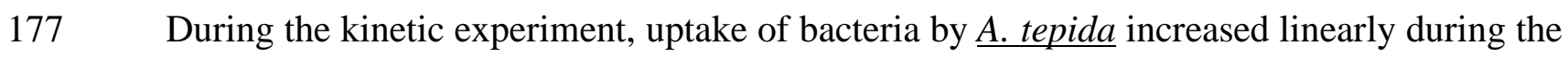

178 first eight hours of incubation and then levelled off (Fig. 1). The linear regression slope for

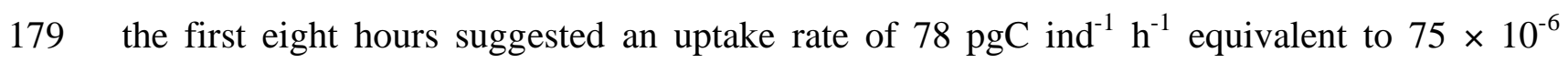

$180 \mathrm{gC}_{\text {bacteria }} \mathrm{gC}_{\text {Ammonia }}{ }^{-1} \mathrm{~h}^{-1}\left(\mathrm{r}^{2}=0.99\right)$. The linear regression slope between eight and twelve hours

181 was more than five times lower than for the first eight hours and suggested an uptake rate of $18214 \mathrm{pgC}$ ind $^{-1} \mathrm{~h}^{-1}$.

183 Temperature had a significant effect on $\underline{\text { Ammonia }}$ uptake rate of bacteria $(F=27$;

$184 \mathrm{p}<0.001)$. Temperatures tested fluctuated between 5 and $40^{\circ} \mathrm{C}$ and were in the range of those

185 found in the study area (Guarini et al. 1997). Uptake of bacteria was almost null at $5^{\circ} \mathrm{C}$, then

186 increased with temperature. It reached an optimum at around $30^{\circ} \mathrm{C}$ and then decreased (Fig.

187 2). Uptake rates measured at 10,20 and $40{ }^{\circ} \mathrm{C}$ were not significantly different. Maximum 


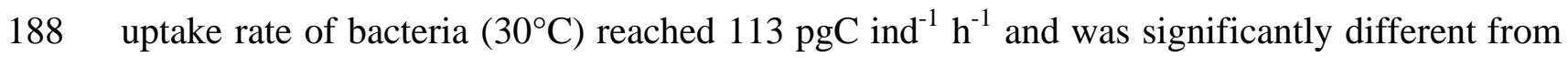
189 others.

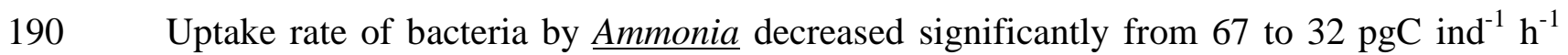
191 when salinity dropped down from 31 to $18 \%$ o (bilateral t-test; p<0.05) (Fig. 3). In the study 192 area, salinity of overlaying water fluctuates between 25 to 35\%o (Héral et al. 1982) but salinity 193 of sediment can be reduced by rainfall.

194 The sediment surface irradiance shifts from dark during submersion and night emersions to 195 high levels of incident light during daytime emersions. Irradiance tested ( $83 \mu \mathrm{M}$ of photons $\left.196 \mathrm{~m}^{-2} \mathrm{~s}^{-1}\right)$ corresponds to a low irradiance. Light did not affect foraminifera feeding activity: 197 uptake rates of bacteria were similar under light and darkness (bilateral t-test; $p=0.71$ ) (Fig. $1983)$.

199 Ingestion of bacteria was significantly linked with abundance of bacteria in microcosm $(F$ $200=32 ; \mathrm{p}<0.001)($ Fig. 4). Four different bacterial concentrations were tested: 4, 7, 10 and $17 \times$ $20110^{8}$ cells $\mathrm{ml} \mathrm{wt} \mathrm{sed}{ }^{-1}$. There was no uptake when the bacterial abundance was $4 \times 10^{8}$ cells ml

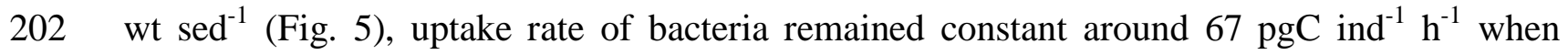

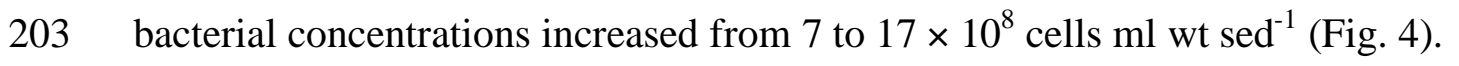

204 When algal concentration increased from 15 to $114 \mu \mathrm{gChla} \mathrm{g} \mathrm{dry}$ sed $^{-1}$ with constant 205 bacterial abundance $\left.\left(10.5 \times 10^{8} \text { cell ml}\right)^{-1}\right)$, the uptake rate of bacteria remained constant $(\mathrm{F}=$ 206 1.4; $\mathrm{p}=0.29$ ) (Fig. 5). The uptake rate of algae increased from 329 to $971 \mathrm{pgC} \mathrm{ind}^{-1} \mathrm{~h}^{-1}$ 207 linearly when algal abundance increased $\left(r^{2}=0.99 ; p<0.001\right)$ (Fig. 7). When algal abundance 208 increased, the fraction of algae in the diet of foraminifera increased. The fraction of bacteria 209 decreased from 18.8 to 14.4 and $7.8 \%$ of microbes (algae plus bacteria) taken up when algal

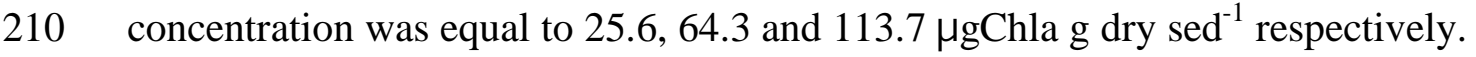




\section{Discussion}

212 Experimental procedure

213 Like all various methods previously developed and applied to measure bacterivory, the 214 method used in the present study presents methodological shortcomings that make

215 interpretation of the resulting problematic. For instance, sieving the sediment changes the 216 bacterial availability for foraminifera, bacteria being not attached to particle as in natural 217 situation. Foraminifera are known to selectively graze different bacterial strains (Lee et al. 218 1966; Bernhard and Bowser 1992). As grazing experiments are based on the hypothesis that 219 grazers take up ${ }^{15} \mathrm{~N}$ enriched bacteria and natural sediment bacteria at the same rate, the 220 cultured bacteria community has to present characteristics roughly similar to the natural one.

221 Despite the fact that culture modified the specific composition of the natural bacterial 222 community, characteristics of size, activity and diversity of the cultured bacterial consortium 223 in our experiments would be more representative of the natural community than in most 224 previous grazing experiments (Pascal et al. 2008). As enriched algae (monospecific and 225 freeze-dried) may present characteristics different from natural algal community, bias due to 226 selective ingestion of algae may exist. Control experiments were always performed in similar 227 conditions to assess bias due to bacterial or algal cell adhesion on foraminiferal test. ${ }^{13} \mathrm{C}$ 228 enriched freeze dried algae are potential source of enriched DOM and transfer to bacteria 229 drive to formation of ${ }^{13} \mathrm{C}$ enriched bacteria but as incubations were short-term, we consider as 230 negligible this bias due to recycling.

231 The kinetics of bacterial uptake

232 Foraminifera use pseudopodia in order to form a long and extensive network for trapping 233 food particles (Travis and Bowser 1991). Actively feeding specimens are characterized by 234 feeding cysts. Aggregates of particles are firmly attached around the test apertures and they may encompass the entire test. Collected material is partitioned into small fractions before 
ingestion. The possibility of extracellular digestion (Meyer-Reil and Köster 1991) and reticulopodial digestion (Lee et al. 1991) has been suggested. Food vacuoles contain large amounts of sediment, organic detritus, algal cells and bacteria (Goldstein and Corliss 1994).

Those vacuoles are most abundant in the terminal chamber, but occur throughout the last four chambers as well. The digestion of bacteria seems to occur in the terminal chamber of

241 Ammonia (Goldstein and Corliss 1994; Langezaal et al. 2005). This genus ingests bacteria and 242 readily digests them, implying that bacteria are more probably used as food source than as 243 symbionts (Langezaal et al. 2005).

244 Langezaal et al. (2005) found that Ammonia beccarii grazed 90 bacteria during a $20 \mathrm{~h}$ 245 period. Converting their uptake rate into bacterial biomass (Norland et al. 1995), gives a

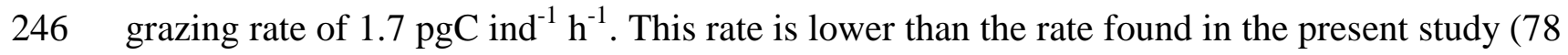
$247 \mathrm{pgC} \mathrm{ind}^{-1} \mathrm{~h}^{-1}$ ). This may be linked to the bacterial concentration used by Langezaal et al. 248 (2005) in their microcosms $\left(1.4 \times 10^{3}\right.$ cells $\left.\mathrm{ml}^{-1}\right)$, which was substantially lower than benthic 249 bacterial abundance in natural environments (c.a. $10^{9}$ cells $\mathrm{ml}^{-1}$ ) and in the present study.

250 In present experiments, uptake of bacteria by $\underline{\text { Ammonia }}$ was rapid and detectable after 2 251 hours of incubation (Fig. 1). This is in accordance with Moodley et al. (2000) who observed a 252 detectable uptake of algal carbon by Ammonia after three hours of incubation. Uptake of 253 bacteria increased linearly during the first eight hours and then levelled off (Fig. 1). A similar 254 pattern was observed for uptake of algae by Ammonia (Moodley et al. 2000). This levelling 255 off may reflect satiation or more likely excretion, effective after eight hours. Foraminifera 256 have been reported to assimilate ingested algal carbon within $12 \mathrm{~h}$ (Rivkin and De Laca 1990) 257 and $\underline{\text { Ammonia }}$ was found to assimilate carbon from phytodetritus in $12 \mathrm{~h}$ (Moodley et al. 258 2000). A simplified energy budget can be calculated with following parameters, $C=A+F U$ 259 ( $C=$ food uptake, $A=$ assimilation of metabolisable energy, $F U=$ loss by faeces and urinary 260 wastes) (Klekowski et al. 1979; Schiemer 1982). We suggest that during the first eight hours 
of incubation, Ammonia takes up and assimilates bacteria. Then, after eight hours, uptake and

262 assimilation still occur but excretion begins. By assuming, that uptake is constant during all 263 the grazing experiments, assimilation and excretion rates can be assessed. The first slope from

264 the origin to eight hours would correspond to the uptake rate while the second slope would 265 correspond to the assimilation rate. Ammonia retains five times more tracer during the first 266 eight hours than after. As a result, $17 \%$ of ingested bacteria would be assimilated and $83 \%$ 267 would be rejected. This result is disputable because the uptake rate constancy was not 268 determined and the uptake rate after eight hours is determined from only two data points, 269 however, this result fits well with assimilation rate of bacteria by nematodes (25\%) (Herman 270 and Vranken 1988) and polychaetes (26\%) (Clough and Lopez 1993).

\section{$271 \quad$ Effects of abiotic factors}

272 Studies on the influence of environmental factors on Ammonia are limited. However, 273 Bradshaw $(1957 ; 1961)$ determined the influence of temperature and salinity on $\underline{\text { Ammonia }}$ 274 reproductive activity, growth rate and survival under experimental conditions.

275 In the present experiments, temperature had a similar effect on uptake rate of bacteria to 276 the one shown by Bradshaw on growth and reproductive rates. We found no uptake of 277 bacteria at $5^{\circ} \mathrm{C}$ (Fig. 2), in accordance with Bradshaw, showing that foraminifera metabolism 278 is very low at low temperatures. Under a temperature less than $10^{\circ} \mathrm{C}$, Ammonia fail to grow 279 and reproduce and individuals appear to live an indefinitely long period (Bradshaw 1957). 280 The optimal grazing temperature appeared at $30^{\circ} \mathrm{C}$ (Fig. 2) as in Bradshaw's experiments 281 (Bradshaw 1961). When temperature exceeded $30^{\circ} \mathrm{C}$ in our microcosms, grazing rate 282 decreased. Similarly, no growth was observed in Bradshaw's experiments, and specimens 283 lived less than one day at $35^{\circ} \mathrm{C}$ (Bradshaw 1957). Those physiological characteristics have 284 implications for foraminiferal abundances at the seasonal time scale. Limited activity during 285 winter prevents reproduction and limits abundance, while in summer, high temperature can 
lead to mortality, in particular in the intertidal habitat subject to a wide range of rhythmically 287 and rapidly varying temperature due to tidal cycles.

288 Uptake rate of bacteria declined when salinity was reduced to $18 \%$ (Fig. 3). This result is 289 also in accordance with those of Bradshaw (1957; 1961). According to this author, normal 290 growth and reproduction of Ammonia occur when salinity fluctuates between 20 and 40\%o, 291 and Ammonia failed to grow below 13\%o. Ammonia is an euryhaline genus found from 292 brackish (Debenay and Guillou 2002) to hypersaline environments (Almogi-Labin et al. 293 1992). However, conditions of brackish environments would not be optimal for Ammonia. 294 Foraminifera use a network of pseudopoda to gather and ingest food particles. Each 295 pseudopoda contains an elongated cytoskeleton primarily composed of microtubules. 296 Modifications of salinity induce a decrease of the number of pseudopodal microtubules 297 (Koury et al. 1985), that may lead to a lower pseudopodal efficiency. This could explain the 298 lower uptake rate observed at low salinity, considering that sediment salinity is under control 299 of tidal cycles and weather conditions, like rainfall, which induces a strong decrease of 300 salinity during low tide.

301 Light did not affect uptake rate of $\underline{\text { Ammonia }}$ (Fig. 3). Although foraminifera frequently 302 form symbiosis with algae, Ammonia is not known as an algal-bearing foraminifera (Lee and 303 Anderson 1991). Consequently, irradiance would not influence feeding behaviour of 304 Ammonia. This is confirmed by our grazing experiment results with a low irradiance rate. 305 Owing to this, Ammonia seems not influenced by nycthemeral cycles and seems able to graze 306 in superficial sediment exposed to sun in the temperature range that allows grazing. This 307 suggests that Ammonia is able to feed actively in environment affected by irradiance 308 variations. 
310 Sedimented organic carbon from the photic zone can represent a major food source for 311 deep-sea benthic foraminifera (Gooday 1988). Many studies report that the abundance of 312 benthic foraminifera assemblages is strongly correlated with surface ocean productivity (e. g. 313 Altenbach et al. 1999; Fontanier et al. 2002). Quick uptake of phytodetritus was observed 314 within the deep sea but also within shallow water dwellers (Middelburg et al. 2000; Moodley et al. 2000; Moodley et al. 2002; Moodley et al. 2005; Nomaki et al. 2005a; Nomaki et al. 2005b). This high reactivity to food pulses may imply that uptake rates are strongly linked with food abundance and type of food.

318 Theoretically, food uptake by a grazer increases with abundance of food. However, above 319 a threshold value of prey concentration, uptake rate remains constant (Holling's preydependent type II functional response (Holling 1959)). Uptake of bacteria is not detectable at 321 the lowest bacterial concentration of $4.2 \times 10^{8}$ cells $\mathrm{ml} \mathrm{wt} \mathrm{sed}^{-1}$ (Fig. 4). This lack of uptake 322 may occur for different reasons. One possibility could be that foraminifera does not feed at 323 low bacterial concentrations. Most probably, the ratio between enriched and non-enriched 324 bacteria used in our experiments was not high enough to allow uptake detection at low concentration. Above $7 \times 10^{8}$ cells $\mathrm{ml}$ wt $\mathrm{sed}^{-1}$, the rate of uptake of bacteria remained constant, despite the increased of bacterial abundance (Fig. 5). The threshold value of prey 327 abundance may have been overshot, which would mean that uptake by Ammonia would 328 seldom be higher than those measured. Bacterial abundance in superficial marine sediment is relatively constant around $10^{9}$ cells $\mathrm{ml} \mathrm{wt} \mathrm{sed}^{-1}$ and seldom lower than $7 \times 10^{8}$ cells $\mathrm{ml}_{\mathrm{wt}} \mathrm{sed}^{-}$

$330{ }^{1}$ (Schmidt et al. 1998). According to these data, bacterial abundance in natural environment 331 would always satisfy the Ammonia optimal uptake rate and would never be limiting factor for 332 uptake. 
Algal uptake rate increased linearly with algal abundance reaching $971 \mathrm{pgC}$ ind $^{-1} \mathrm{~h}^{-1}$ without levelling off for the tested values (Fig. 5). Algal abundances used during this experiment (15 to $114 \mu \mathrm{gChla} g$ dry $\operatorname{sed}^{-1}$ ) are not high enough to reach the maximum algal uptake rate; indeed $\underline{\text { Ammonia }}$ was found to graze at a higher rate on $\underline{\text { Chlorella }}\left(2180 \mathrm{pgC} \mathrm{ind}^{-1}\right.$

However, through vertical migration, benthic microalgae concentrate near the surface during

340 diurnal low tides producing a biofilm. In this algal mat, concentration of chlorophyll $a$ can 341 reach $150 \mu \mathrm{gChla} g$ dry $\operatorname{sed}^{-1}$ (Serôdio et al. 1997) and even $300 \mu \mathrm{gChla} \mathrm{g} \mathrm{dry} \mathrm{sed}{ }^{-1}$ (Kelly et 342 al. 2001). Ammonia feeding on the algal biofilm would then present a higher uptake rate than 343 in the present study.

344 The use of differential labelling of bacterial food $\left({ }^{15} \mathrm{~N}\right)$ and algal food $\left({ }^{13} \mathrm{C}\right)$ allows to 345 access simultaneous uptake rates of bacteria and algae, thus permitting to determine the 346 preferred item according to their availability. While algal uptake increased with algal 347 abundance, uptake of bacteria remained constant (Fig. 5). Ammonia still ingested bacteria 348 when other food resources were available. Bacteria might be a source of essential compounds 349 for deposit feeders (Lopez and Levinton 1987). This assumption is in accordance with Muller 350 and Lee (1969) who suggested that some foraminifera reproduce only when bacteria are 351 present as food source. Then, uptake of bacteria would be essential for Ammonia.

352 Uptake of bacteria by Ammonia never represented more than $19 \%$ of microbial biomass 353 (bacteria plus algae) taken up. This low contribution of bacteria to food uptake was also 354 observed with algal concentrations comparable with sediment natural conditions of $25 \mu \mathrm{g}$ 355 Chla g dry $\operatorname{sed}^{-1}$ (MacIntyre et al. 1996). Muller (1975) suggest that shallow water dwelling 356 species mainly depend on algal resources. In their study, van Oevelen et al. (2006) found that 
bacterial carbon constitutes only $9 \%$ of total needs of hard-shelled foraminifera of an intertidal mudflat community.

In intertidal areas, algal abundances vary seasonally (e. g. Haubois et al. 2005). In addition, benthic microalgae of intertidal sediments vertically migrate with rhythms associated with diurnal and tidal cycles (Blanchard et al. 2001). During day time, at low tide, algal cells

362 concentrate near the surface of sediment and form a mat (Herlory et al. 2004). According to our results, $\underline{\text { Ammonia }}$ seems to depend principally on algal feeding resource. For this reason, this species may feed on the mat of microphybenthos when it is formed in order to maximize its rate of energy gain. This feeding behaviour would imply that Ammonia dwells at the

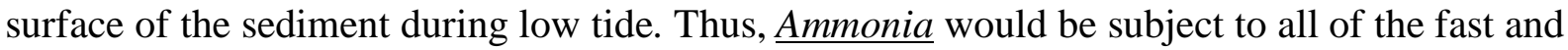

367 large environmental variations that are typical of the intertidal habitat, especially at the air368 sediment interface during low tide. Though Ammonia is considered as one of the most tolerant 369 genus of foraminifera to temperature and salinity variations (Bradshaw 1961; Walton and 370 Sloan 1990), we showed that variations of these parameters influence uptake of bacteria (Fig.

3712 and 3). Vertical migration from the food-rich surface into deeper layers is a possible 372 mechanism for foraminifera to avoid unfavourable conditions (Groß 2002). In this deeper 373 layer, bacteria would constitute a large part of the diet of Ammonia. When temperature and

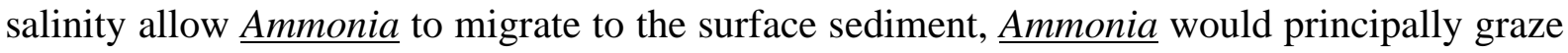
375 on the microphytobenthic mat.

376 In conclusion, bacteria appeared to be quantitatively of minor importance in the nutrition 377 of foraminifera compared to algae. The present work demonstrates that, at the tidal scale, 378 grazing rate of bacteria is affected by abiotic (temperature and salinity) whereas it would not 379 be affected by biotic (algal and bacterial abundances) factors. A. tepida may further respond 380 to environmental changes at a seasonal scale, by physiological adjustment and shifting of its 
381 optimum conditions. However, the present study does not permit to evaluate this acclimation

382 capacity and more efforts need to be made to take it into account.

\section{Acknowledgements}

384 We thank Amélie Sallon for her help in sample preparation, Gaël Guillou for isotopic 385 analyses and Utte Wollenzien from NIOO-CEMO for giving us a Navicula phyllepta strain.

386 We are grateful to Eleanor Jones for English corrections. The "Conseil Général de Charente

387 Maritime", the programme ECCO, the programme PNEC - Chantier Littoral Atlantique and 388 the ANR-VASIREMI financially supported this work. 


\section{References}

Almogi-Labin A, Perelis-Grossovicz L, Raab M (1992) Living Ammonia from a hypersaline inland pool, Dead Sea area, Israël. J Foraminifer Res 22: 257-266

Alongi DM (1992) Benthic infauna and organism-sediment relations in a shallow, tropical coastal area: influence of outwelled mangrove detritus and physical disturbance. Mar Ecol Prog Ser 81: 229-245

Altenbach AV (1992) Short term processes and patterns in the foraminiferal response to organic flux rates. Mar Micropaleontol 19: 119-129

Altenbach AV, Pflaumann N, Schiebel U, Thies A, Timm S, Trauth M (1999) Scaling percentages and distribution patterns of benthic foraminifera with flux rates of organic carbon. J Foraminifer Res 29: 173-185

Antia NJ, Cheng JY (1970) The survival of axenic cultures of marine phytoplankton algae from prolonged exposure to darkness at $20^{\circ} \mathrm{C}$. Phycologia 9: 179-183

Bernhard JM (2003) Potential symbionts in bathyal foraminifera. Science 299: 861

Bernhard JM, Bowser SS (1992) Bacterial biofilms as a trophic resource for certain benthic foraminifera. Mar Ecol Prog Ser 83: 263-272

Blanchard GF, Guarini JM, Orvain F, Sauriau PG (2001) Dynamic behaviour of benthic microalgal in intertidal mudflats. J Exp Mar Biol Ecol 264: 85-100

Bradshaw JS (1957) Laboratory studies of the rate of growth of the foraminifera Streblus beccarii (Linné), var. tepida Cushman. J Paleontol 31: 1138-1147

Bradshaw JS (1961) Laboratory experiment on the ecology of foraminifera. Contr Cushman Found Res 12: 87-106

Clough LM, Lopez GR (1993) Potential carbon sources for the head down deposit-feeding polychaete Heteromastus filiformis. J Mar Res 51: 595-616

Debenay J-P, Guillou J-J (2002) Ecological transitions indicated by foraminiferal assemblages in paralic environments. Estuaries 25: 1107-1120

Degré D, Leguerrier D, Armynot du Chatelet E, Rzeznik-Orignac J, Auguet J-C, Dupuy C, Marquis E, Fichet D, Struski C, Joyeux E, Sauriau P-G, Niquil N (2006) Comparative analysis of the food webs of two intertidal mudflats during two seasons using inverse modelling: Aiguillon Cove and Brouage Mudflat, France. Est Coast Shelf Sci 69: 107124

Fontanier C, Jorissen FJ, Licari L, Alexandre A, Anschutz P, Carbonel P (2002) Live benthic foraminiferal faunas from the Bay of Biscay: faunal density, composition and microhabitats. Deep-Sea Res 49: 751-785

Goldstein ST, Corliss JO (1994) Deposit feeding in selected deep-sea and shallow-water benthic foraminifera. Deep-Sea Res 41: 229-441

Gooday AJ (1988) A response by benthic foraminifera to the deposition of phytodetritus in the deep-sea. Nature 332: 70-73

Gooday AJ, Levin LA, Linke P, Heeger T (1992) The role of benthic foraminifera in deep-sea food webs and carbon cycling. In: Rowe GT, Parient V (eds) Deep-sea Food Chains and the global Carbon Cycle. Kluwer, Dordrecht, pp 63-91

Groß O (2002) Sediment interactions of foraminifera: implications for food degradation and bioturbation processes. J Foraminifer Res 32: 414

Guarini JM, Blanchard GF, Gros P, Harrison SJ (1997) Modeling the mud surface temperature on intertidal flats to investigate the spatio-temporal dynamics of the benthic microalgal photosynthetic capacity. Mar Ecol Prog Ser 153: 25-36

Haubois AG, Sylvestre F, Guarini JM, Richard P, Blanchard GF (2005) Spatio-temporal structure of the epipelic diatom assemblage from an intertidal mudflat in MarennesOléron Bay, France. Est Coast Shelf Sci 64: 385-394 
Héral M, Razet D, Deslous-Paoli JM, Bertome JP, Garnier J (1982) Caractéristiques saisonnières de l'hydrologies du complexe estuarien de Marennes-Oléron (France). Revue des travaux de l'institut des pêches maritimes 46: 97-119

Herlory O, Guarini JM, Richard P, Blanchard GF (2004) Microstructure of microphytobenthic biofilm and its saptio-temporal dynamics in an intertidal mudflat (Aiguillon Bay, France). Mar Ecol Prog Ser 282: 33-44

Herman PMJ, Vranken G (1988) Studies of the life history and energetics of marine and brackish water nematodes. II. Production, respiration and food-uptake by Monhystera disjuncta. Oecologia 77: 457-463

Holling CS (1959) Some characteristics of simple types of predation and parasistism. Canadian Entomologist 91: 385-398

Kelly JA, Honeywill C, Paterson DM (2001) Microscale analysis of chlorophyll-a in cohesive intertidal sediments: the implications of microphytobenthos distribution. J Mar Biol Ass U K 81: 151-162

Klekowski RZ, Schiemer F, Duncan A (1979) A biogenic study of a benthic nematode, Plectrus palustris de Man 1880, throughout its life cycle. Oecologia 44: 119-124

Koury ST, Bowser SS, MacGee-Russel SM (1985) Ultrastructure changes during reticulopod withdrawal in the foraminiferan protozoan Allogromia sp., Strain NF. Protoplasma 129: $149-156$

Langer MR, Gehring CA (1993) Bacteria farming: a possible feeding strategy of some smaller, motile foraminifera. J Foraminifer Res 23: 40-46

Langezaal AM, Jannink NT, Pierson ES, van der Zwaan GH (2005) Foraminiferal selectivity towards bacteria: an experimental approach using cell-permeant stain. J Sea Res 54: 256-275

Lee JJ, Anderson OR (1991) Symbiosis in foraminifera. In: Lee JJ, Anderson OR (eds) Biology of foraminifera. Academic Press, New-York, pp 157-220

Lee JJ, Faber WW, Lee RE (1991) Granular reticulopodial digestion - a possible preadaptation to benthic foraminifera symbiosis ? Symbiosis 10: 47-61

Lee JJ, Mc Enery M, Pierce S, Freudenthal HD, Muller WA (1966) Tracer experiments in feeding littoral foraminifera. J Protozool 16: 659-670

Lee JJ, Muller WA (1973) Trophic dynamics and niches of salt marsh foraminifera. Am Zool 13: $215-223$

Leguerrier D, Niquil N, Boileau N, Rzeznik J, Sauriau PG, Le Moine O, Bacher C (2003) Numerical analysis of the food web of an intertidal mudflat ecosystem on the Atlantic coast of France. Mar Ecol Prog Ser 246: 17-37

Leguerrier D, Niquil N, Petiau A, Bodoy A (2004) Modeling the impact of oyster culture on a mudflat food web in Marennes-Oléron Bay (France). Mar Ecol Prog Ser 273: 147-162

Levinton JS (1979) Deposit feeding and coastal oceanography. In: Lopez G, Taghon GL, Levinton JS (eds) Ecology of marine deposit feeders. Springer-Verlag, New-York, pp $1-23$

Linke P, Altenbach AV, Graf G, Heeger T (1995) Responses of deep-sea benthic foraminifera to a simulated sedimentation event. J Foraminifer Res 25: 75-82

Lipps JH (1983) Biotic interactions in benthic foraminifera. In: Tevesz MJS, Mc Call PL (eds) Biotic interactions in recent and fossil benthic communities. Plenum Press, NewYork, pp 331-373

Lopez GR, Levinton JS (1987) Ecology of deposit-feeding animals in marine sediments. Q Rev Biol 62: 235-260

Lorenzen S (1966) A method for the continuous measurement of in vivo chlorophyll concentration. Deep-Sea Res 13: 223-227 
MacIntyre HL, Geider RJ, Miller DC (1996) Microphytobenthos: the ecological role of the "secret garden" of unvegetated, shallow-water marine habitats. I. Distribution, abundance and primary production. Estuaries 19: 186-201

Mariotti A (1982) Apports de la géochimie isotopique à la connaissance du cycle de l'azote. PhD Thesis, Paris, pp 476

Meyer-Reil LA, Köster M (1991) Fine-scale distribution of hydrolytic activity associated with foraminiferans and bacteria in deep-sea sediments of the Norwegian-Greenland sea. Kieler Meeresforsch., Sonderhelf 8: 121-126

Middelburg JJ, Barranguet C, Boschker HTS, Herman PMJ, Moens T, Heip CHR (2000) The fate of intertidal microphytobenthos carbon. An in situ ${ }^{13} \mathrm{C}$ labelling study. Limnol Oceanogr 45: 1224-1234

Moodley L, Boshker HTS, Middelburg JJ, Pel R, Herman P, de Deckere E, Heip CHR (2000) Ecological significance of benthic foraminifera: ${ }^{13} \mathrm{C}$ labelling experiments. Mar Ecol Prog Ser 202: 289-295

Moodley L, Heip HR, Middelburg JJ (1998) Benthic activity in sediments of the northwestern Adriatic Sea: sediment oxygen consumption, macro- and meiofauna dynamics. J Sea Res 40: 263-280

Moodley L, Middelburg JJ, Boschker HTS, Duineveld R, Pel R, Herman PMJ, Heip CHR (2002) Bacteria and foraminifera: key players in a short-term deep sea benthic response to phytodetritus. Mar Ecol Prog Ser 236: 23-29

Moodley L, Middelburg JJ, Soetaert K, Boschker HTS, Herman PMJ, Heip CHR (2005) Similar rapid response to phytodetritus deposition in shallow and deep-sea sediments. J Mar Res 63: 457-469

Muller WA (1975) Competition for food and other niche-related studies of three species of salt-marsh Foraminifera. Mar Biol 31: 339-351

Muller WA, Lee JJ (1969) Apparent indispensability of bacteria in foraminiferan nutrition. J Protozool 16: 471-478

Murray JW (1991) Ecology and paleoecology of benthic foraminifera, New-York

Nomaki H, Heinz P, Hemleben C, Kitatzao H (2005a) Behavior and response of deep-sea benthic foraminifera to freshly supplied organic matter: a laboratory feeding experiment in microcosm environments. J Foraminifer Res 35: 103-113

Nomaki H, Heinz P, Nakatsuka T, Shimanaga M, Kitazato H (2005b) Species-specific ingestion of organic carbon by deep-sea benthic foraminifera and meiobenthos: In situ tracer experiments. Limnol Oceanogr 50: 134-146

Norland S, Fagerbakka KM, Heldal M (1995) Light element analysis of individual bacteria by X-ray microanalysis. Appl Environ Microbiol 61: 1357-1362

Pascal PY, Dupuy C, Mallet C, Richard P, Niquil N (2008) Bacterivory by benthic organism in sediment: quantification using- ${ }^{15} \mathrm{~N}$ enriched bacteria. J Exp Mar Biol Ecol 355: 1826

Porter KG, Feig YS (1980) The use of DAPI for identifying and counting aquatic microflora. Limnol Oceanogr 25: 943-948

Rivkin RB, De Laca TE (1990) Trophic dynamics in Antartic benthic communities. I. In situ ingestion of microalgae by foraminifera and metazoan meiofauna. Mar Ecol Prog Ser 64: $129-136$

Schiemer F (1982) Food dependence and energetics of freeliving nematodes. I. Respiration, growth and reproduction of Caenorhabditis briggsae (Nematoda) at different levels of food supply. Oecologia 54: 108-121

Schmidt JL, Deming JW, Jumars PA, Keil RG (1998) Constancy of bacterial abundance in surficial marine sediments. Limnol Oceanogr 43: 976-982 
536 Serôdio J, da Silva JM, Catarino F (1997) Nondestructive tracing of migratory rhythms of intertidal benthic microalgae using in vivo chlorophyll a fluorescence. J Phycol 33: $542-553$

Snider LJ, Burnett BR, Hessler RR (1984) The composition and distribution of meiofauna and nanobiota in a central North Pacific deep-sea area. Deep-Sea Res 31: 1225-1249

Travis JL, Bowser SS (1991) The mobility of foraminifera. In: Lee JJ, Anderson NH (eds) Biology of foraminifera. Academic Press, London, pp 91-155

Underwood GJC, Kromkamp JC (2000) Primary production by phytoplancton and microphytoplancton in estuaries. In: Nedwell DB, Raffaelli DG (eds) Estuaries, Advances in Ecological Research. Academic Press, pp 93-153

van Oevelen D, Moodley L, Soetaert K, Middelburg JJ (2006) The trophic significance of bacterial carbon in a marine intertidal sediment: Results of an in situ stable isotope labeling study. Limnol Oceanogr 51: 2349-2359

Walton WR, Sloan BJ (1990) The genus Ammonia Brünnich, 1772: its geographic distribution and morphologic variability. J Foraminifer Res 20: 128-156 
Table 1. Foraminiferal isotopic compositions $\left(\Delta^{15} \mathrm{~N}\right.$ and $\Delta^{13} \mathrm{C}$ means $\left.\pm \mathrm{SD}, \mathrm{N}=3\right)$ and

554 bacterial and algal uptake rates calculated.

555 Figure 1. Bacteria uptake (mean $\pm \mathrm{SD}, \mathrm{N}=3$ ) as function of incubation time (h).

556 Figure 2. Bacteria uptake rate (mean $\pm \mathrm{SD}, \mathrm{N}=3$ ) as function of temperature $\left({ }^{\circ} \mathrm{C}\right)$.

557 Different letters above bars indicate significant differences between incubation conditions

558 (ANOVA; Tukey test).

$559 \quad$ Figure 3a $\&$ 3b. Bacteria uptake rate (mean $\pm \mathrm{SD}, \mathrm{N}=3$ ) under low versus high salinity

560 (a) and dark versus light incubation (b). * indicate significant difference (t-test).

561 Figure 4. Bacteria uptake rate (mean $\pm \mathrm{SD}, \mathrm{N}=3$ ) as function of bacteria abundance $\left(10^{8}\right.$

562 cell $\mathrm{ml} \mathrm{wt} \mathrm{sed}^{-1}$ ). Different letters above bars indicate significant differences between 563 incubation conditions (ANOVA; Tukey test).

564 Figure 5. Algae uptake rate $\bigcirc($ mean $\pm S D, N=3)$ and bacteria uptake rate $\bigcirc$ (mean \pm

$565 \mathrm{SD}, \mathrm{N}=3$ ) as function of algal abundance ( $\mu \mathrm{gChla} g$ dry wt sed ${ }^{-1}$ ) under constant bacteria 566 abundance $\left(10.5 \times 10^{8}\right.$ cell $\left.\mathrm{ml} \mathrm{wt} \mathrm{sed}^{-1}\right)$. 


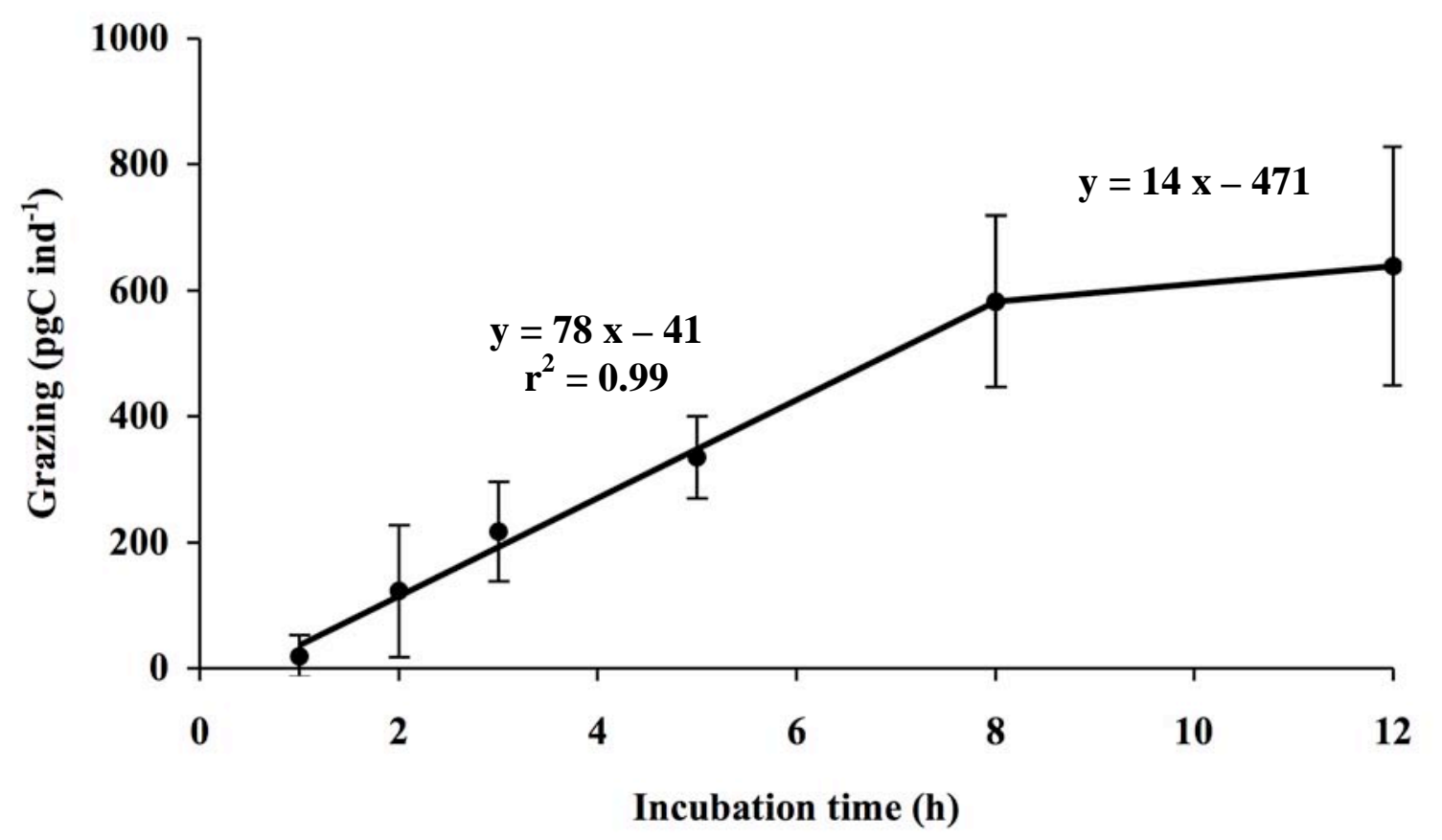

Fig. 1

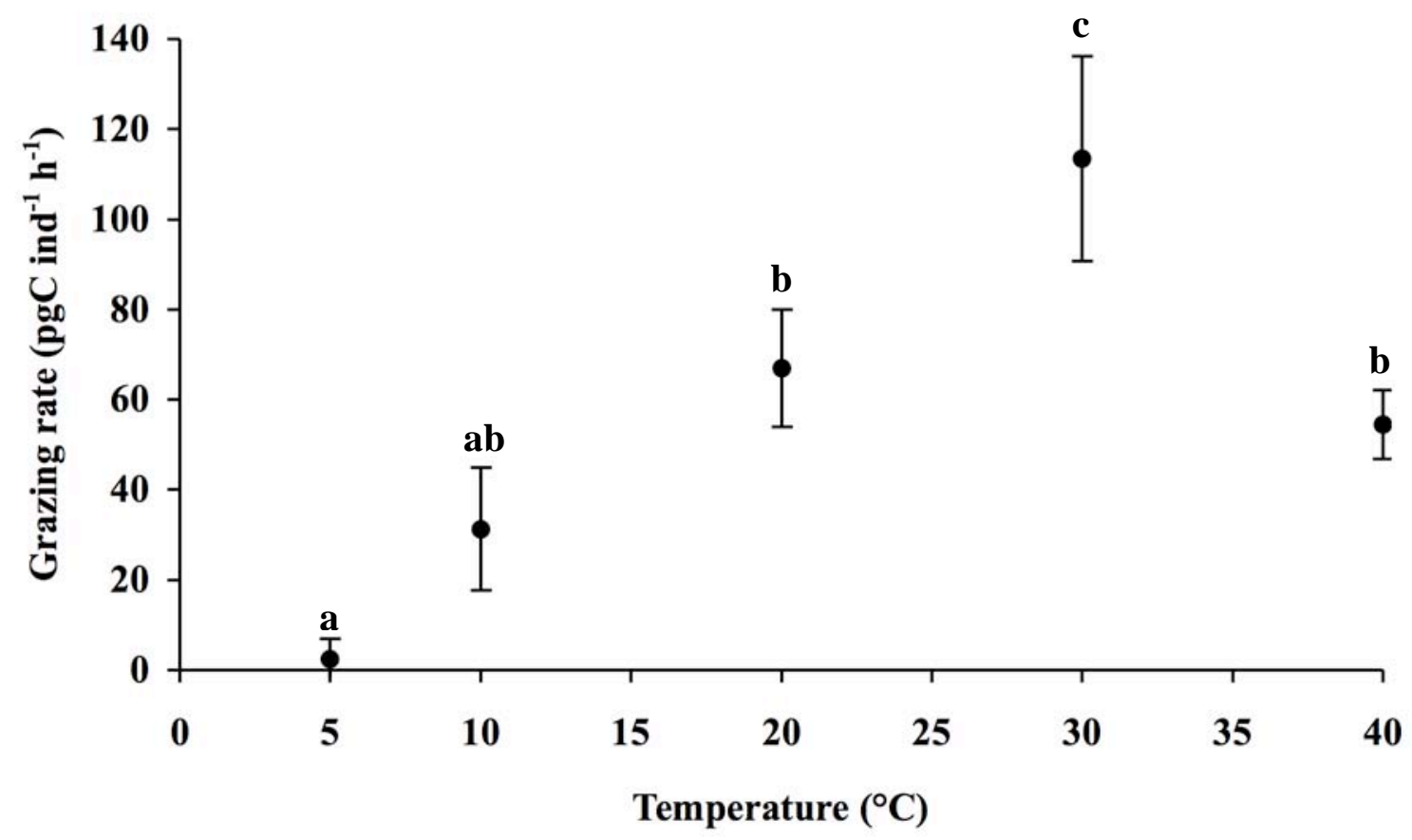

Fig. 2 

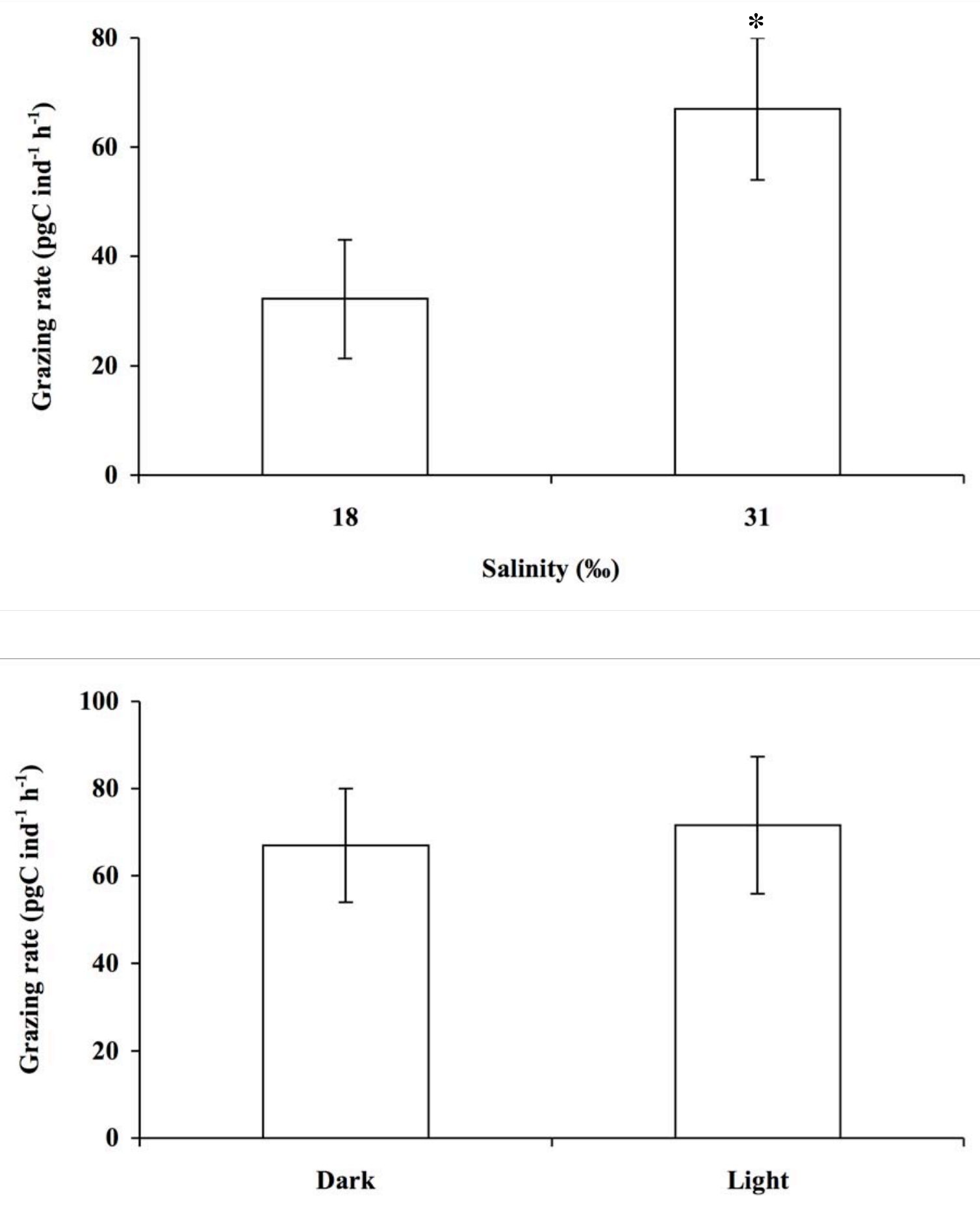

Fig. 3a \& 3b 


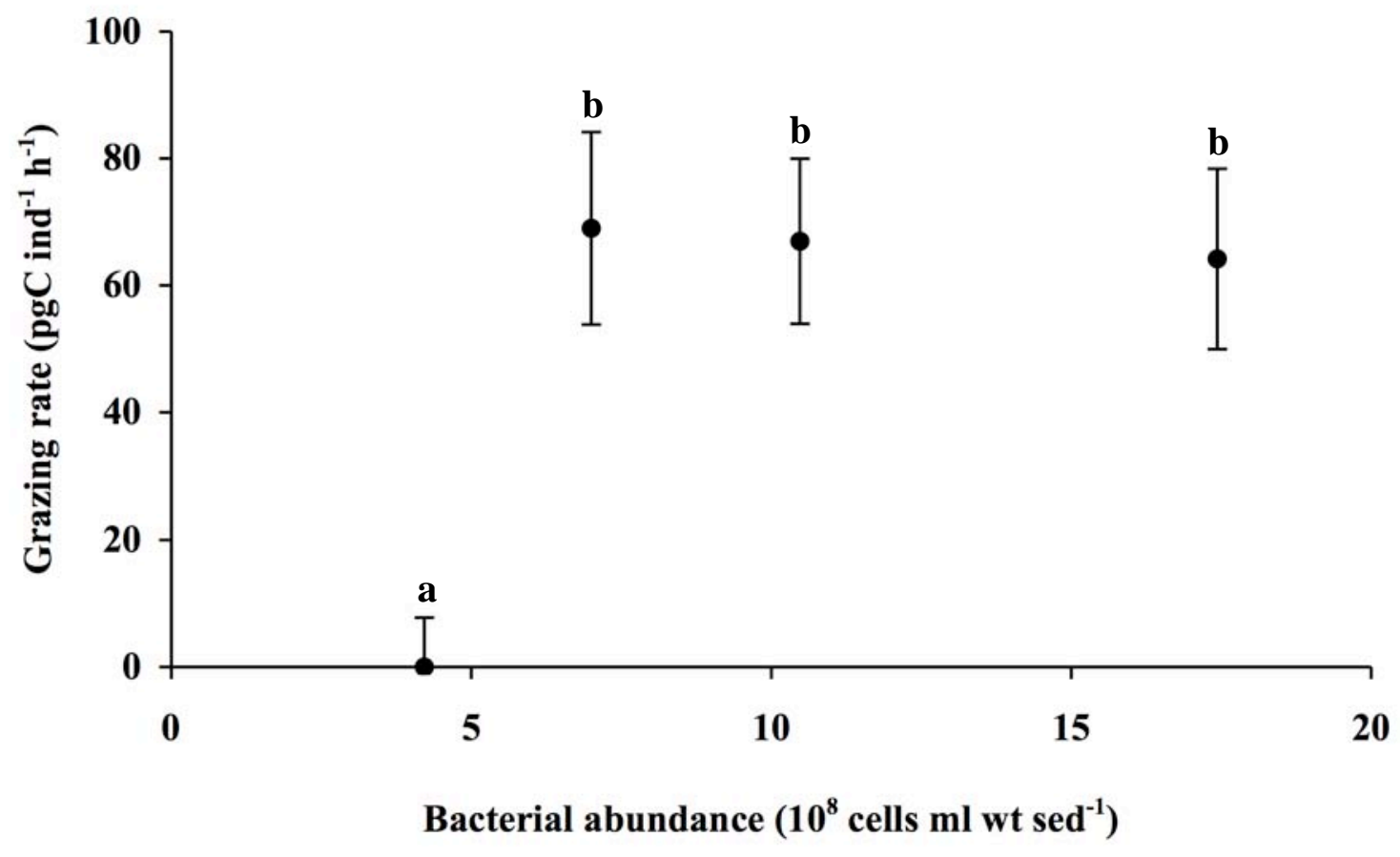

Fig. 4

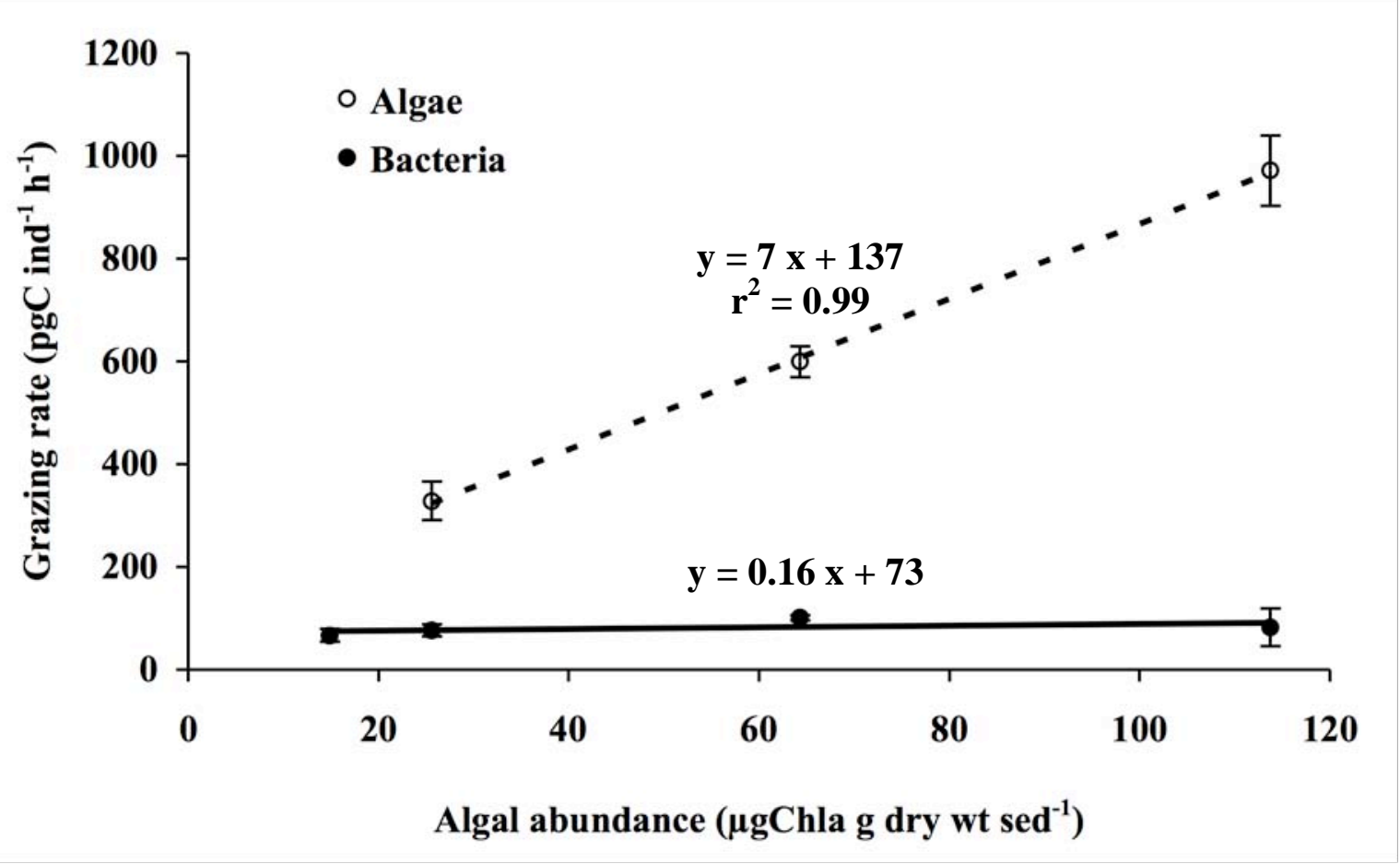

Fig. 5 


\begin{tabular}{|c|c|c|c|}
\hline & \multicolumn{2}{|c|}{$\Delta^{15} \mathbf{N}$} & \multirow{2}{*}{$\begin{array}{l}\text { Bacteria uptake } \\
\left(\text { pg C } \text { ind }^{-1} h^{-1}\right)\end{array}$} \\
\hline & Control & Normal & \\
\hline netics (hours) & & & \\
\hline 1 & $13.21 \pm 0.33$ & $13.40 \pm 0.33$ & $19.07 \pm 33.03$ \\
\hline 2 & $13.27 \pm 0.18$ & $14.50 \pm 1.06$ & $61.29 \pm 52.57$ \\
\hline 3 & $14.83 \pm 0.12$ & $17.02 \pm 0.79$ & $72.35 \pm 26.24$ \\
\hline 5 & $16.70 \pm 0.19$ & $20.08 \pm 0.66$ & $66.96 \pm 13.00$ \\
\hline 8 & $16.45 \pm 0.21$ & $22.33 \pm 1.37$ & $72.83 \pm 16.97$ \\
\hline 12 & $17.23 \pm 0.48$ & $23.67 \pm 1.91$ & $53.20 \pm 15.80$ \\
\hline
\end{tabular}

Temperature $\left({ }^{\circ} \mathbf{C}\right)$

5
10
30
40

Irradiance

Light

Salinity

18

Bacterial abundance

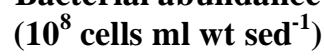

$$
\begin{aligned}
& 4.2 \\
& 7.0
\end{aligned}
$$

17.4

Algal abundance ( $\mu \mathrm{g}$ Chla g dry sed ${ }^{-1}$ )

$$
\begin{array}{|r|}
25.6 \\
64.3 \\
113.7
\end{array}
$$

Tab. 1$$
113.7
$$

$\begin{array}{ll}15.89 \pm 0.45 & 16.01 \pm 0.23 \\ 15.11 \pm 0.34 & 16.68 \pm 0.69 \\ 16.71 \pm 0.63 & 22.44 \pm 1.15\end{array}$

$18.53 \pm 0.24 \quad 21.28 \pm 0.39$

$18.07 \pm 0.19 \quad 21.69 \pm 0.79$

$16.24 \pm 0.48 \quad 17.87 \pm 0.55$

$32.22 \pm 10.82$

$12.83 \pm 0.10 \quad 12.82 \pm 0.11$

$14.10 \pm 0.10 \quad 16.70 \pm 0.57$

$20.96 \pm 1.67 \quad 24.86 \pm 0.86$

$0.84 \pm 7.78$

$69.00 \pm 15.16$

$64.17 \pm 14.20$

$16.70 \pm 0.19$

$16.94 \pm 0.08$

$17.48 \pm 0.60$

$20.55 \pm 0.57$ $22.03 \pm 0.29$

$21.63 \pm 1.84$

$2.44 \pm 4.54$

$1.24 \pm 13.63$

$13.44 \pm 22.77$

$54.42 \pm 7.65$

$71.65 \pm 15.73$

Control $\Delta^{13} \mathrm{C}$ Normal

Algae uptake

(2)

